\title{
Prevalence and risk factors associated with brucellosis among high-risk individuals in Lafia, Nasarawa state, Nigeria
}

\author{
Charity Ashe'osla Agada ${ }^{1}$, Jibrin Mohammed ${ }^{1,2}$, Anthony Ekele Joseph Okoh ${ }^{1}$ and Joseph Akwoba Ogugua ${ }^{3}$ \\ 1. Department of Veterinary Public Health and Preventive Medicine, College of Veterinary Medicine, University of \\ Agriculture, Makurdi, Nigeria; 2. Department of Animal Science, School of Agriculture, College of Agriculture, Lafia, \\ Nasarawa State, Nigeria; 3. Department of Veterinary Public Health and Preventive Medicine, Faculty of Veterinary \\ Medicine, University of Nigeria, Nsukka, Nigeria. \\ Corresponding author: Charity Ashe'osla Agada, e-mail: caysla@gmail.com \\ Co-authors: JM: salma13000@yahoo.com, AEJO: profokohanthon45@gmail.com, JAO: akwoba.ogugua@gmail.com \\ Received: 27-07-2018, Accepted: 27-08-2018, Published online: 23-09-2018
}

doi: 10.14202/IJOH.2018.45-51 How to cite this article: Agada CA, Mohammed J, Okoh AEJ, Ogugua JA (2018) Prevalence and risk factors associated with brucellosis among high-risk individuals in Lafia, Nasarawa state, Nigeria. Int J One Health $2018 ; 4: 45-51$.

\begin{abstract}
Background and Aim: Brucellosis caused by Brucella species is a zoonotic disease prevalent in Nigeria. Data on this disease in humans and its risk factors in Lafia, Nasarawa State, are lacking. This study was, therefore, designed to determine the prevalence of brucellosis and the risk factors among individuals most at risk in Lafia, Nasarawa State.
\end{abstract}

Materials and Methods: This study was conducted on high-risk individuals in the area using the Rose Bengal test (RBT) and questionnaire.

Results: Out of the 160 respondents tested for seropositivity to brucellosis, $10 \%(16 / 160)$ prevalence was recorded with the RBT. None of the factors evaluated was found to be significantly associated with the seroprevalence of brucellosis in the area. On the other hand, final logistic regression analysis found the knowledge of brucellosis to be significantly associated with the profession $(\mathrm{OR}=11.52 ; 95 \% \mathrm{CI}=1.47-90.46 ; \mathrm{p}=0.02)$ and age $(\mathrm{OR}=2.6 ; 95 \% \mathrm{CI}=1.11-4.19 ; \mathrm{p}=0.023)$. Furthermore, practices that expose to Brucella infection were found to be significantly associated with the site $(\mathrm{OR}=4.02 ; 95 \% \mathrm{CI}=5.29$ 333.33; $\mathrm{p}=0.000)$ and marital status $(\mathrm{OR}=2.44 ; 95 \% \mathrm{CI}=1.03-5.75 ; \mathrm{p}=0.042)$.

Conclusion: Brucellosis is prevalent among occupationally exposed individuals in Lafia. There should be continued surveillance for the disease and education of high-risk individuals in the area.

Keywords: age, brucellosis, humans, Lafia, prevalence, profession.

\section{Introduction}

Brucellosis is an infectious zoonotic disease which has a debilitating chronic effect in humans and reproductive failure in domestic animals. Although eradicated in most developed countries, brucellosis is a disease of major public health and economic importance in developing countries where it is endemic [1]. The importance of brucellosis is most pronounced in rural areas due to the close contact between livestock and man especially when the incomes of the people rely heavily on livestock breeding and dairy products. In developed countries, there has been a decline in the incidence of human brucellosis as a result of pasteurization and eradication programs [2,3]. Human brucellosis is, therefore, regarded as a travel-associated or occupational disease in these areas [4].

Brucellosis is the most common zoonotic disease worldwide with more than 500,000 new cases reported in humans annually [5]. However, this number

Copyright: Agada, et al. This article is an open access article distributed under the terms of the Creative Commons Attribution 4.0 International License (http://creativecommons.org/licenses/ by/4.0/), which permits unrestricted use, distribution, and reproduction in any medium, provided you give appropriate credit to the original author(s) and the source, provide a link to the Creative Commons license, and indicate if changes were made. The Creative Commons Public Domain Dedication waiver (http:// creativecommons.org/ publicdomain/zero/1.0/) applies to the data made available in this article, unless otherwise stated. underestimates the real picture of the incidence of the disease because clinical picture, which is most commonly relied upon for disease diagnosis in the developing countries, varies greatly [6]. In addition, poor disease reporting and misdiagnosis have also contributed in no small measure to mask the extent of damage caused by the disease in Sub-Sahara Africa [7]. More so, brucellosis has been described as one of the "great imitators" as it presents similar clinical signs as many endemic diseases such as malaria and typhoid $[8,9]$ making it difficult to diagnose clinically.

Direct contact with infected abortion materials, inhalation, and the consumption of infected milk and milk products are significant means of transmission of the disease to humans [10]. It is, therefore, an occupational disease to farmers, veterinarians, abattoir workers, and laboratory workers while the general public is mainly at the risk of exposure through consumption of infected raw milk and milk products [11-14]. All these sources of disease transmission are relevant in Nigeria because of its prevalence in livestock [15]. Although risk factors for brucellosis infection are related to cultural and occupational factors, these cannot be extrapolated from one society to another [16]. This makes it imperative to undertake a survey of the disease among such individuals at risk in Nasarawa State where such data on brucellosis is scarce. 
Brucellosis in humans, cattle, sheep, goats, pigs, and $\operatorname{dog}_{s}$ has been reported in Nigeria [10,17-22]. In the rural communities, many people keep livestock in and around the homes. Indeed, the Fulani herdsmen sleep in the midst of cattle herds in the field to protect them from poachers, cattle rustlers, and wild animals. Again, fresh milk and soft cheese (Wara) are sold directly or through vendors to the public. Although studies have shown that brucellosis is sufficiently common in humans, hospitals rarely diagnose the disease in Nigeria $[17,23]$. It is, therefore, important to assess the spread of the disease among highrisk individuals and identify associated risk factors for Brucella infection to provide informed control measures against this debilitating disease in Nigeria.

This study was, therefore, designed to determine the prevalence of brucellosis and the risk factors among individuals most at risk in Lafia, Nasarawa State.

\section{Materials and Methods}

\section{Ethical approval}

The ethical permission with approval number $\mathrm{MOH} / \mathrm{OFF} / 237 / 1 / \mathrm{XX}$ for this study was obtained from the Nasarawa State Ministry of Health; permission was also obtained from the Management of abattoir and Ardors (Head of the Fulani Communities).

\section{Informed consent}

Consent was obtained from each participant after the purpose, benefits, and possible adverse effects of the study had been explained.

\section{Study area}

This study was conducted in Lafia Local Government Area (LGA), Nasarawa State. The LGA is in the state capital where a central abattoir and a cattle market exist. Furthermore, quite a good number of workers in the neighborhood consume unpasteurized cow milk. Drinking of unpasteurized milk, working in the cattle market or slaughter slab constitute high risks of exposure to Brucella infection.

\section{Study design}

This was a cross-sectional study conducted in the abattoir, cattle markets, and cattle herds to determine the prevalence and risk factors for the occurrence of brucellosis among individuals that work in these areas.

\section{Sample size}

The sample size was calculated using the statistical formula, $\mathrm{n}=1.96^{2} P \exp (1-P \exp ) / \mathrm{d}^{2}$ as earlier cited [21] based on hospital prevalence of $7.6 \%$ in fever patients in Nigeria [17], a total of 108 samples from the high-risk (hospital) patients were calculated. However, a total of 160 samples were collected.

\section{Sample collection and handling}

Blood samples (4-5 mL) were collected from the consenting participants by phlebotomists in the hospitals. The blood samples were decanted into centrifuge bottles without anticoagulant. The samples were taken to the Laboratory of the Department of Veterinary Public Health and Preventive Medicine, University of Agriculture Makurdi in flasks containing ice packets. The blood samples in the bottles without lithium heparin were allowed to clot and then centrifuged at $3000 \mathrm{rpm}$ for $5 \mathrm{~min}$. Serum samples were decanted and stored at $-20^{\circ} \mathrm{C}$ until they were assayed. The serum samples were examined by Rose Bengal test (RBT) [24].

\section{Questionnaire survey}

An interviewer-administered structured questionnaire was used to obtain data from each participant after collecting the sample. The questionnaire was pre-tested in the field and adjusted to improve clarity. Data on age, tribe, occupation, knowledge of brucellosis, consumption of raw milk, ownership of animals, the occurrence of abortion in the animals kept, as well as methods of self-protection employed when in contact with livestock or their products, etc., were collected.

\section{Scoring of knowledge}

The scoring of knowledge was based on a respondent's claims to know brucellosis could be supported with the ability to name correctly (without suggestions from the interviewer) four clinical signs of brucellosis. With each regarded as one point, knowledge was, therefore, scored using a five points scale. Scores ranging from zero to two points were rated as poor and three to five points as good knowledge.

\section{Scoring of practice}

The scoring of practice was based on practices that enhance exposure or non-exposure of the respondents to Brucella infection. There were 10 questions that were considered. A respondent that engaged in five good practices was scored as good but poor if the respondent scored less. However, there were two critical questions that were scored poor once the respondent engaged in any of them. A respondent who touched aborted fetus or placenta and assisted in parturition without wearing gloves or drank milk without boiling, but did not engage in any other practices that could enhance exposure to Brucella infection was considered to engage in the poor practice. Some of the practices examined included consumption of unpasteurized milk, assisting in parturition without proper personal protective covering, touching aborted fetus without wearing gloves, etc.

\section{Statistical analysis}

Data collected were entered into excel spreadsheets and analyses were performed using the statistical software package STATA version 12 (StataCorp LP, USA). Data were analyzed to determine the association between Brucella infection and the demographic characteristics, knowledge, and practices. Furthermore, the association between demographic characteristics and knowledge as well as practices of the respondents with respect to brucellosis was determined. Group differences were tested using Chi-square 
statistics for categorical variables. A multi-variable adjusted logistic regression was carried out using all the variables that were statistically significant at the $10 \%$ level with the main outcome measures (seropositivity to RBT, knowledge, and practices) in bivariate analysis. All tests were two-tailed and statistical significance $(\alpha)$ was set at 0.05 .

\section{Results}

The result of the study showed seropositivity in $10.00 \%(16 / 160)$ of the 160 individuals screened with RBT. Furthermore, while the level of good knowledge of brucellosis was low (41.88\%), practices that expose to the disease was high $(66.25 \%)$ among the respondents. Prevalence of brucellosis was higher in urban $10.53 \%(12 / 114)$ than rural areas $(8.70 \%)$; in abattoir workers $(12.50 \%)$ than other professional groups screened $(9.72 \%)$; in young $(10.7 \%)$ than old $(8.96 \%)$, in females $(20.00 \%)$ than males $(9.68 \%)$, also in those not living with their spouses $(13.51 \%)$ than those living with their spouses $(8.94 \%)$. Seropositivity to brucellosis among the respondents in the study was found to be higher in those with secondary or higher education $(10.34 \%)$ than those with primary or no education (9.80\%) and among the Fulani (10.43\%) than other ethnic groups $(8.89 \%)$. The study also recorded the prevalence of brucellosis to be higher in those with poor $(10.75 \%)$ than good $(8.96 \%)$ knowledge and in those that engaged in poor $(10.38 \%)$ than good $(9.26 \%)$ practices. However, none of the factors considered was found to be significantly associated with seropositivity to brucellosis among the respondents screened (Table-1).

The final logistic regression analysis recorded a significant association between knowledge and profession $(\mathrm{OR}=11.52 ; 95 \% \mathrm{CI}=1.47-90.46 ; \mathrm{p}=0.02)$ with abattoir personnel being 12 times more likely than those in other professions to have knowledge of brucellosis. Knowledge of brucellosis among the respondents was also found to be associated with age $(\mathrm{OR}=2.6 ; 95 \% \mathrm{CI}=1.11-4.19 ; \mathrm{p}=0.023)$ with the young respondents being about 2 times more likely than the older respondents to have knowledge of the disease (Table-2 and 3). The study found practices that expose to brucellosis to be associated with site $(\mathrm{OR}=4.02$; 95\% $\mathrm{CI}=5.29-333.33 ; \mathrm{p}=0.000$ ) with rural dwellers being about 4 times more likely to engage in unhygienic practices than those in the urban areas. Practices that could expose to brucellosis were also found to be associated with the marital status (OR=2.44; 95\% $\mathrm{CI}=1.03-5.75 ; \mathrm{p}=0.042$ ) (Tables-4 and 5).

\section{Discussion}

The study found brucellosis to be prevalent among the respondents tested for brucellosis in Nasarawa State. This finding has both economic and public health implications considering the loss of person hours, cost of treatment and possible death associated with the disease. This prevalence in humans may be linked to the prevalence of the disease among livestock in Nasarawa State [22] and other middle belt states of Nigeria where farmers in the state also purchase new or replacement stock [18,25-27]. Such prevalence in livestock translates to the occurrence of the disease in in-contact persons [28,29].

The prevalence recorded $(10 \%)$ is comparable to the $7.6 \%$ recorded among hospital patients in Makurdi [17] but lower than the $21.7 \%$ documented among abattoir workers in Abuja [30] and $24.1 \%$ also in Abuja [25], 31.82\% in abattoir workers in Oyo State [23], 15.6\% in Angola [31], 32.9\%

Table-1: Factors associated with seroprevalence of brucellosis as measured with the RBT among high-risk persons in Lafia, Nasarawa State.

\begin{tabular}{|c|c|c|c|c|c|}
\hline Variable & Characteristic & $\begin{array}{c}\text { Positive } \\
\text { n (\%) }\end{array}$ & $\begin{array}{c}\text { Negative } \\
\text { n (\%) }\end{array}$ & Chi-square & p-value \\
\hline \multirow[t]{2}{*}{ Site } & Urban & $12(10.53)$ & $102(89.47)$ & 0.1220 & 0.727 \\
\hline & Rural & $4(8.70)$ & $42(91.3)$ & & \\
\hline \multirow[t]{2}{*}{ Profession } & Abattoir personnel & $2(12.50)$ & $14(87.50)$ & 0.1235 & 0.725 \\
\hline & Others ${ }^{\gamma}$ & $14(9.72)$ & $130(90.2)$ & & \\
\hline \multirow[t]{2}{*}{ Age } & Young & $10(10.75)$ & $83(89.25)$ & 0.1398 & 0.708 \\
\hline & Old & $6(8.96)$ & $61(91.04)$ & & \\
\hline \multirow[t]{2}{*}{ Gender } & Male & $15(9.68)$ & $140(90.32)$ & 0.5735 & 0.449 \\
\hline & Female & $1(20.000$ & $4(80.00)$ & & \\
\hline \multirow[t]{2}{*}{ Religion } & Islam & $14(10.61)$ & $118(89.39)$ & 0.3078 & 0.579 \\
\hline & Others $^{\delta}$ & $2(7.14)$ & $26(92.86)$ & & \\
\hline \multirow[t]{2}{*}{ Marital status } & Living with spouse & $11(8.94)$ & $112(91.06)$ & 0.6602 & 0.416 \\
\hline & Not living with spouse & $5(13.51)$ & $32(86.49)$ & & \\
\hline \multirow[t]{2}{*}{ Education } & Little or no formal education & $10(9.80)$ & $92(90.20)$ & 0.020 & 0.913 \\
\hline & Enough formal education & $6(10.34)$ & $52(89.66)$ & & \\
\hline \multirow[t]{2}{*}{ Ethnicity } & Fulani & $12(10.43)$ & 103 (89.57) & 0.877 & 0.769 \\
\hline & Others & $4(8.89)$ & $41(91.11)$ & & \\
\hline \multirow[t]{2}{*}{ Knowledge } & Good & $6(8.96)$ & $61(91.04)$ & 0.1398 & 0.708 \\
\hline & Poor & $10(10.75)$ & $83(89.25)$ & & \\
\hline \multirow[t]{2}{*}{ Practices } & Good & $5(9.26)$ & $49(90.74)$ & & \\
\hline & Poor & $11(10.38)$ & $95(89.62$ & & \\
\hline
\end{tabular}

$\gamma=$ Burcher, pastoralists, and livestock traders, ${ }^{\delta}=$ Christianity, traditional religion, and others 
Table-2: Factors influencing levels of knowledge about brucellosis amongst high-risk persons in Lafia Nasarawa State, Nigeria $(n=160)$.

\begin{tabular}{|c|c|c|c|c|c|}
\hline Variable & Category & $\begin{array}{c}\text { Good knowledge } \\
\text { n (\%) }\end{array}$ & $\begin{array}{c}\text { Poor knowledge } \\
\text { n (\%) }\end{array}$ & Chi-square & p-value \\
\hline \multirow[t]{2}{*}{ Site } & Urban & $46(40.35)$ & $68(59.65)$ & 0.3784 & 0.538 \\
\hline & Rural & $21(45.65)$ & $25(54.35)$ & & \\
\hline \multirow[t]{2}{*}{ Profession } & Abattoir personnel & $1(6.25)$ & $15(93.75)$ & 9.2698 & 0.002 \\
\hline & others $\gamma$ & $66(45.83)$ & $78(54.17)$ & & \\
\hline \multirow[t]{2}{*}{ Age } & Young & $31(33.33)$ & $62(66.67)$ & 0.6573 & 0.010 \\
\hline & Old & $36(53.73)$ & $31(46.27)$ & & \\
\hline \multirow[t]{2}{*}{ Gender } & Male & $66(42.58)$ & $89(57.42)$ & 1.0147 & 0.314 \\
\hline & Female & $1(20.00)$ & $4(80.00)$ & & \\
\hline \multirow[t]{2}{*}{ Religion } & Islam & $59(44.70)$ & $73(55.30)$ & 2.4679 & 0.116 \\
\hline & Others $\delta$ & $8(28.57)$ & $20(71.43)$ & & \\
\hline \multirow[t]{2}{*}{ Marital status } & Living with spouse & $54(43.90)$ & $69(56.10)$ & 0.8983 & 0.343 \\
\hline & Not living with spouse & $13(35.14)$ & $24(64.86)$ & & \\
\hline \multirow[t]{2}{*}{ Education } & Little or no formal education & $41(40.20)$ & $61(59.80)$ & 0.3259 & 0.568 \\
\hline & Enough formal education & $26(44.83)$ & $32(55.17)$ & & \\
\hline \multirow[t]{2}{*}{ Ethnicity } & Fulani & $22(48.89)$ & $23(51.11)$ & 1.2654 & 0.262 \\
\hline & Others & $45(39.13)$ & $70(60.87)$ & & \\
\hline
\end{tabular}

$\gamma=$ Burcher, pastoralists, and livestock traders, ${ }^{\delta}=$ Christianity, traditional religion, and others

Table-3: Multivariable unconditional logistic regression analysis of factors influencing levels of knowledge about brucellosis among high-risk persons in Lafia Nasarawa State, Nigeria $(n=160)$.

\begin{tabular}{llccccc}
\hline Variable & Characteristic & $\begin{array}{c}\text { Good knowledge } \\
\text { n (\%) }\end{array}$ & $\begin{array}{c}\text { Poor knowledge } \\
\text { n (\%) }\end{array}$ & OR & 95\% (CI) & p-value \\
\hline Profession & Abattoir personnel & $1(6.25)$ & $15(93.75)$ & 11.52 & $1.47-90.46$ & 0.020 \\
& Others & $66(45.83)$ & $78(54.17)$ & & & $0.11-4.19$ \\
Age & Young & $31(33.33)$ & $62(66.67)$ & 2.16 & 1.113 \\
& Old & $36(53.73)$ & $31(46.27)$ & & & \\
\hline
\end{tabular}

$\gamma=$ Burcher, pastoralists, and livestock traders

Table-4: Factors associated with practices that could aid exposure to Brucella infection among high-risk persons in Lafia, Nasarawa State $(n=160)$

\begin{tabular}{|c|c|c|c|c|c|}
\hline Variable & Characteristic & $\begin{array}{c}\text { Good Practices } \\
\text { n (\%) }\end{array}$ & $\begin{array}{c}\text { Poor Practices } \\
\text { n (\%) }\end{array}$ & Chi-square & p-value \\
\hline \multirow[t]{2}{*}{ Site } & Urban & $53(46.49)$ & $61(53.51)$ & 28.7892 & 0.000 \\
\hline & Rural & $1(2.17)$ & $45(97.83)$ & & \\
\hline \multirow[t]{2}{*}{ Profession } & Abattoir personnel & $10(62.50)$ & $6(37.50)$ & 6.5719 & 0.010 \\
\hline & Others $\gamma$ & $44(30.56)$ & $100(69.44)$ & & \\
\hline \multirow[t]{2}{*}{ Age } & Young & $27(29.03)$ & $66(70.97)$ & 2.2107 & 0.137 \\
\hline & Old & $27(40.30)$ & $40(59.70)$ & & \\
\hline \multirow[t]{2}{*}{ Gender } & Male & $50(32.26)$ & $105(67.74)$ & 4.9377 & 0.026 \\
\hline & Female & $4(80.00)$ & $1(20.00)$ & & \\
\hline \multirow[t]{2}{*}{ Religion } & Islam & $40(30.30)$ & $92(69.70)$ & 4.008 & 0.045 \\
\hline & Others $\delta$ & $14(50.00)$ & $14(50.00)$ & & \\
\hline \multirow[t]{2}{*}{ Marital status } & Living with spouse & $36(29.27)$ & $87(70.73)$ & 4.7781 & 0.029 \\
\hline & Not living with spouse & $18(48.65)$ & $19(51.35)$ & & \\
\hline \multirow[t]{2}{*}{ Education } & Little/no formal education & $25(24.51)$ & $77(75.49)$ & 10.7447 & 0.001 \\
\hline & Good formal education & $29(50.00)$ & $29(50.00)$ & & \\
\hline \multirow[t]{2}{*}{ Ethnicity } & Fulani & $6(13.33)$ & $39(86.67)$ & 11.6720 & 0.001 \\
\hline & Others & $48(41.74)$ & $67(58.26)$ & & \\
\hline
\end{tabular}

$\gamma=$ Burcher, pastoralists, and livestock traders, $\delta=$ Christianity, traditional religion, and others

Table-5: Multivariate unconditional logistic regression analysis of factors associated with practices that expose to Brucella infection among high-risk persons in Lafia, Nasarawa State

\begin{tabular}{llccccc}
\hline Variable & Characteristic & $\begin{array}{c}\text { Good practices } \\
\mathbf{n}(\mathbf{\%})\end{array}$ & $\begin{array}{c}\text { Poor practices } \\
\mathbf{n}(\mathbf{\%})\end{array}$ & OR & 95\% (CI) & p-value \\
\hline Site & Urban & $53(46.49)$ & $61(53.51)$ & 0.249 & $0.0032-0.189$ & 0.000 \\
\multirow{2}{*}{ Marital status } & Rural & $1(2.17)$ & $45(97.83)$ & & & 0.042 \\
& Living with spouse & $36(29.27)$ & $87(70.73)$ & 2.435 & $1.03-5.75$ & 0 \\
& Not living with spouse & $18(48.65)$ & $19(51.35)$ & & & \\
\hline
\end{tabular}


in Pakistan [5], 60.0\% among abattoir workers in Sudan [32], and $21.7 \%$ among abattoir workers in Pakistan [30]. This lower rate may be due to the fact that the Brucella abortus which is most common in Nigeria $[33,34]$ is less readily transmissible and less pathogenic to humans than Brucella melitensis and Brucella suis [25]. In addition, it could be because the disease is endemic in the areas resulting in many infected people being in chronic stage of the disease or getting re-infected which are challenging to diagnose serologically $[35,36]$.

Brucellosis seropositivity was higher among those with inadequate knowledge and those that engage in unhygienic practices that expose to the disease although not significant. Such poor knowledge and practices also recorded among livestock workers in Nigeria in other studies $[25,37]$ result in continued transmission of the disease to the group. With poor knowledge and the resultant unhygienic practices, the cycle of exposing to brucellosis may continue unabated given that although the disease is prevalent in Nigeria, there is no policy for the control of the disease in the country $[7,23]$. There is, therefore, the need for continued education of livestock workers in Nigeria, especially as it concerns the zoonotic nature of the disease.

Although the study found unhygienic practices to be 4 times more frequently met in rural dwellers in comparison with the urban respondents, seropositivity to brucellosis was slightly higher in urban than rural dwellers. This may be attributed to the fact that rural dwellers are more likely to have regular contact with livestock. In endemic areas where animal breeding is a significant source of living, regular contact with livestock may mean regular exposure to the disease $[25,38,39]$. Continued exposure to brucellosis results in poor diagnosis due to chronicity, relapse, or continued reinfection and its better done with the Coombs test $[36,40]$. This could be explained by the fact that in human Brucella infection, the immunoglobulin isotypes found in the blood in early and/or acute infections are the immunoglobulin $\mathrm{M}$ ( $\operatorname{IgM})$ and IgG1 [41], which may not be seen in those with insidious onset, chronic, recurrent, and relapse cases [36] where $\operatorname{IgG} 2, \operatorname{IgG} 3$, and $\operatorname{IgA}$ are predominant [42]. However, the Coombs (anti-human globulin) test is used to monitor chronic and relapse infections because of its better ability to detect IgG and IgA in human sera [43]. Although RBT was reported to be able to detect IgG3 and IgA with modifications of the conventional methods such as serial dilution of the sera samples and reading the test after $8 \mathrm{~min}$ instead of the traditional 4 min by Díaz et al. [42], this work did not employ these modifications. The fact that although this study found that the young respondents were twice more likely to have knowledge of brucellosis, engaged in better hygienic practices than the old, but the prevalence of the disease was higher among the young than the old reiterate the above point.
In spite of the findings, the study had some limitations: First, the only test employed in the study was RBT. The Coombs test which would have been good support was not carried out due to unavailability of reagents. Although it has always been the practice to use more than one serological method in the study of brucellosis, RBT has been advocated as the best test to use in areas where brucellosis is prevalent, and vaccination not routinely practiced [34] and could be used as the only test in such areas [44]. The RBT has also been reported to be better than the complement fixation test in endemic areas where vaccination is not regularly practiced [45]. According to Corbel [46], in such areas, the RBT has excellent capabilities. Indeed, a study that employed stringent meta-analysis showed that the RBT is better than both the iELISA and the cELISA and that these two cannot be used to "confirm" results of a superior test like the RBT [34] especially in endemic areas with no vaccination histories. Furthermore, for the diagnosis of human brucellosis, the RBT has been reported to be only inferior to the Coombs test [47]. Second, the study did not include the isolation of the Brucella organism responsible for the disease in the study area. Although isolation is the gold standard for the diagnosis of the disease, serology alone has been validly used in studies of brucellosis in Nigeria and other countries $[15,25,48,49]$.

\section{Conclusion}

The study found brucellosis to be prevalent among the high-risk groups tested. The respondents generally had poor knowledge of brucellosis and engaged in unhygienic practices. It is, therefore, necessary that the education of individuals in the livestock industry be carried out in the study area. Contrary to this, efforts at controlling the disease in Nigeria will be in futility. Furthermore, the government should make haste to embark on policies for the control of the disease in the country.

\section{Authors' Contributions}

CAA, JM, and AEJO conceived and designed the study, CAA, JM, and JAO carried out sampling and laboratory analysis. JAO drafted the manuscript and carried out the statistical analysis while CAA, JAO and AEJO analyzed and interpreted the data. All authors read and approved the final manuscript.

\section{Acknowledgments}

We acknowledge the Department of Veterinary Public Health and Preventive Medicine, College of Veterinary Medicine, University of Agriculture, Makurdi, Nigeria, for support facility and conducive environment provided. The study was funded by the authors.

\section{Competing Interests}

The authors declare that they have no competing interests. 


\section{References}

1. Baddour MM. Diagnosis of brucellosis in humans : A review. J Vet Adv 2012;2:149-56.

2. World Health Organization. Brucellosis (Human). Excerpt from "WHO Recommended Standards and Strategies for Surveillance, Prevention and Control of Communicable Diseases. Geneva 27, Switzerland: WHO Headquarters; 2005. Available from: http://www.who.int/zoonoses/diseases/ Brucellosissurveillance.pdf. [Last retrieved on 2017 May 05].

3. Yagupsky P. Detection of Brucellae in blood cultures. J Clin Microbiol 1999;37:3437-42.

4. Nimri LF. Diagnosis of recent and relapsed cases of human brucellosis by PCR assay. BMC Infect Dis 2003;3:5.

5. Shahid M, Basit A, Khan MA. Prevalence of brucellosis among the hospital patients of Peshawar, Khyber Pakhtunkhwa. J Inf Mol Biol 2014;2:19-21.

6. Lucero NE, Jacob NO, Ayala SM, Escobar GI, Tuccillo P, Jacques I, et al. Unusual clinical presentation of brucellosis caused by Brucella canis. J Med Microbiol 2005;54:505-8.

7. Ibironke AA, McCrindle CM, Fasina FO, Godfroid J. Evaluation of problems and possible solutions linked to the surveillance and control of bovine brucellosis in sub-Saharan Africa, with special emphasis on Nigeria. Vet Ital 2008;44:549-56.

8. Ariza J, Corredoira J, Pallares R, Viladrich PF, Rufi G, Pujol M, et al. Characteristics of and risk factors for relapse of brucellosis in humans. Clin Infect Dis 1995;20:1241-9.

9. Muchaal P. Zoonoses of Dairy Cattle with Reference to Africa. Ottawa: Cities Feeding People International Development Research Centre (IDRC); 2001. p. 17-9. Available from: http://www.ruaf.org. [Last accessed on 2014 May 20].

10. Onunkwo JI, Njoga EA, Nwanta JA, Shoyinka SV, Onyenwe IW, Eze JI. Serological survey of porcine brucellosis infection in South East, Nigeria. Niger Vet J 2011;32:60-2.

11. Smits HL, Basahi MA, Díaz R, Marrodan T, Douglas JT, Rocha A, et al. Development and evaluation of a rapid dipstick assay for serodiagnosis of acute human brucellosis. J Clin Microbiol 1999;37:4179-82.

12. Demirdal T, Demirturk N. Laboratory-acquired brucellosis. Ann Acad Med 2001;37:86-7.

13. Al-Tawfiq JA, Abukhamsin A. A 24-year study of the epidemiology of human brucellosis in a health-care system in Eastern Saudi Arabia. J Infect Public Health 2009;2:81-5.

14. Megersa B, Biffa D, Niguse F, Rufael T, Asmare K, Skjerve E, et al. Cattle brucellosis in traditional livestock husbandry practice in Southern and Eastern Ethiopia, and its zoonotic implication. Acta Vet Scand 2011;53:24.

15. Cadmus SI, Adesokan HK, Adedokun BO, Stack, JA. Seroprevalence of bovine brucellosis in trade cattle slaughtered in Ibadan, Nigeria, from 2004-2006. J S Afr Vet Assoc 2010;81:50-3.

16. Al-Shamahy HA, Whitty CJ, Wright SG. Risk factors for human brucellosis in Yemen: A case-control. Epidemiol Infect 2000;125:309-13.

17. Ofukwu AR, Yohanna CA, Abuh HA. Brucella infection among hospital patients in Makurdi, North Central Nigeria. Indian J Med Res Pharm Sci 2007;3:63-71.

18. Bertu WJ, Ajogi I, Bale JO, Kwaga JK, Ocholi RA. Seroepidemiology of brucellosis in small ruminants in Plateau State, Nigeria. Afr J Micro Res 2010;4:1935-8.

19. Cadmus SI, Adesokan HK, Ajala OO, Odetokun WO, Perrett LL, Stack JA, et al. Seroprevalence of Brucella abortus and B. canis in household dogs in Southwestern Nigeria: A preliminary report. J S Afr Vet Assoc 2011;82:56-7.

20. Mai HM, Irons PC, Kabir J, Thompson PN. A large seroprevalence survey of brucellosis in cattle herds under diverse production systems in Northern Nigeria. BMC Vet Res 2012;8:144.

21. Agada CA, Goden CP, Ogugua JA. Prevalence of bovine brucellosis and analysis of risk factors in resident cattle herds of Kanke local government area, Plateau State. Niger Vet J 2017;38:104-16.

22. Agada CA, Ogugua AJ, Anzaku EJ. Occurrence of brucellosis in small ruminants slaughtered in Lafia central abattoir, Nasarawa State, Nigeria. Sok J Vet Sci 2018;16:16-23.

23. Cadmus SI, Ijagbone IF, Oputa HE, Adesoko HK, Stack JA. Serological survey of brucellosis in livestock animals and workers in Ibadan, Nigeria. Afr J Biomed Res 2006;9:163-8.

24. Alton GG, Jones LM, Angus ED, Verger JM. Techniques for the Brucellosis Laboratory. Paris: Institute National De La Recherche Agronomique 147, Rue de I'Universite; 1988.

25. Aworh MK, Okolocha E, Kwaga J, Fasina F, Lazarus D, Suleman I, et al. Human brucellosis: Seroprevalence and associated exposure factors among abattoir workers in Abuja, Nigeria-2011. Pan Afr Med J 2013;8688:1-9.

26. Ishaya V, Ndumari W, Ankeli P, Bertu WJ. Isolation of Brucella abortus biotype1 in cattle with bi-lateral hygroma of the forelimb from Logo, Benue State Nigeria: A clinical case report. Int J Livestock Res 2012;2:223-9.

27. Nanven MA, Wungak SY, Gana BA, Nanven MB, Ngbede EO, Ibrahim M, et al. Seroprevalence of bovine brucellosis in Northern Plateau State, North Central Nigeria. Asian Pac J Trop Dis 2013;3:337-40.

28. Pappas G, Papadimitriou P, Akritidis N, Christou L, Tsianos EV. The new global map of human brucellosis. Lancet Infect Dis 2006;6:91-9.

29. Traxler RM, Lehman MW, Bosserman EA, Guerra MA, Smith TL. A literature review of laboratory-acquired brucellosis. J Clin Microbiol 2013;51:3055-62.

30. Mukhtar F, Kokab F. Brucella serology in abattoir workers. J Ayub Med Coll Abbottabad 2008;20:57-61.

31. Mufinda FC, Boinas F, Nunes C. Prevalence and factors associated with human brucellosis in livestock professionals. Rev Saúde Públ 2017;51:1-10.

32. Omer MM, Musa MT, Bakhiet MR, Perrett L. Brucellosis in camels, cattle and humans: Associations and evaluation of serological tests used for diagnosis of the disease in certain nomadic localities in Sudan. Rev Sci Tech 2010;29:663-9.

33. Ocholi RA, Kwaga JK, Ajogi I, Bale JO. Abortion due to Brucella abortus in sheep in Nigeria. Rev Sci Tech 2005;24:973-9.

34. Ducrotoy MJ, Bertu WJ, Ocholi RA, Gusi AM, Bryssinckx W, Welburn S, et al. Brucellosis as an emerging threat in developing economies: Lessons from Nigeria. PLoS Negl Trop Dis 2014;8:e3008.

35. Falade S. A case of possible brucellosis relapse in a veterinarian. Trop Vet 2002;20:226-30.

36. Serra J, Viñas M. Laboratory diagnosis of brucellosis in a rural endemic area in Northeastern Spain. Int Microbiol 2004;7:53-8

37. Adesokan HK, Alabi PI, Stack JA, Cadmus SI. Knowledge and practices related to bovine brucellosis transmission amongst livestock workers in Yewa, South-Western Nigeria. J S Afr Vet Assoc 2013;84:5.

38. Lopes LB, Nicolino R, Haddad JP. Brucellosis-risk factors and prevalence : A review. Open Vet Sci J 2010;4:72-84.

39. Kechagia M, Mitka S, Papadogiannakis E, Kontos V, Koutis C. Molecular detection of Brucella spp. DNA in patients with manifestations compatible with emotional disorders. Open Infect Dis J 2011;5:8-12.

40. Orduña A, Almaraz A, Prado A, Gutierrez MP, GarciaPascual A, Dueñas A, et al. Evaluation of an immunocapture-agglutination test (Brucellacapt) for serodiagnosis of human brucellosis. J Clin Microbiol 2000;38:4000-5.

41. Ismail TF, Smits H, Wasfy MO, Malone JL, Fadeel MA, Mahoney F, et al. Evaluation of dipstick serologic tests for diagnosis of brucellosis and typhoid fever in Egypt. J Clin Microbiol 2002;40:3509-11.

42. Díaz R, Casanova A, Ariza J, Moriyón I. The rose Bengal test in human brucellosis: A neglected test for the diagnosis of a neglected disease. PLoS Negl Trop Dis 2011;5:e950.

43. Smits HL, Abdoel TH, Solera J, Clavijo E, Diaz R. 
Immunochromatographic Brucella-specific immunoglobulin $\mathrm{M}$ and $\mathrm{G}$ lateral flow assays for rapid serodiagnosis of human brucellosis. Clin Diagn Lab Immunol 2003;10:1141-6.

44. Mangen MJ, Otte J, Pfeiffer D, Chlonda P. Bovine Brucellosis in Sub-Saharan Africa: Estimation of SeroPrevalence and Impact on Meat and Milk Offtake Potential (Livestock policy) Discussion Paper; 2002.

45. ICONZ. The Rose Bengal Test (RBT) for the DIAGNOSIS of Brucellosis; 2011. Available from: http//www.icozafrica. org. [Last accessed on 2014 May 10].

46. Corbel MJ. Brucellosis in Humans and Animals. 20 Avenue Appia, 1211 Geneva 27, Switzerland: World Health Organization; 2006. Available from: http://www.who.int/
csr/resources/publications/Brucellosis.pdf. [Last accessed on 2014 May 10].

47. Cernyseva MI, Knjazeva EN, Egorova LS. Study of the plate agglutination test with rose Bengal antigen for the diagnosis of human brucellosis. Bull World Health Organ 1977;55:669-74.

48. Maichomo MW, McDermott JJ, Arimi SM, Gathura PB. Assessment of the Rose-Bengal plate test for the diagnosis of human brucellosis in health facilities in Narok district, Kenya. East Afr Med J 1998;75:219-22.

49. Bayemi PH, Webb EC, Nsongka MV, Unger H, Njakoi H. Prevalence of Brucella abortus antibodies in serum of Holstein cattle in Cameroon. Trop Anim Health Prod 2009;41:141-4.

$* * * * * * * *$ 